\title{
$\beta$-human chorionic gonadotropin assay in vaginal washing fluid for the accurate diagnosis of premature rupture of membranes during late pregnancy
}

\section{Geç gebelik sırasında erken membran rüptürünün doğru tanısı için vajinal yıkama sivisında $\beta$-human koryonik gonodatropin ölçümü}

\author{
Orhan Temel ${ }^{1}$, Ebru Çöğendez ${ }^{1}$, Selçuk Selçuk ${ }^{1}$, Mehmet Reşit Asoğlu², Erdal Kaya ${ }^{1}$ \\ 'Department of Obstetrics and Gynecology, Zeynep Kamil Training and Research Hospital, Istanbul, Turkey \\ ${ }^{2}$ The University of Texas MD Anderson Cancer Center, Houston, Texas, United States of America
}

\section{Abstract}

Objective: To determine whether the measurement of beta-human chorionic gonadotropin ( $\beta$-hCG) levels in vaginal fluid is useful for the diagnosis of premature rupture of membranes (PROM).

Material and Methods: A total of 92 pregnant women between 24 and 40 weeks gestation participated in this study. The patients with fluid leaking from the vagina were designated Group 1, the patients with no fluid leaking from the vagina were Group 2, and those with a suspicion of fluid leaking from the vagina were classified as Group 3. Irrigating the posterior vaginal fornix with $5 \mathrm{~mL}$ sterile saline was used to measure $\beta$-hCG levels of the patients. Receiver operator curve (ROC) analysis was used to determine the cut-off value for a positive diagnosis.

Results: The $\beta$-hCG levels of vaginal fluid were measured as $20.5 \pm 25.0 \mathrm{mIU} / \mathrm{mL}, 254.6 \pm 346.8 \mathrm{mIU} / \mathrm{mL}$, and $74.3 \pm 100.8 \mathrm{mIU} / \mathrm{mL}$ in Group 1, Group 2, and Group 3, respectively. Vaginal $\beta$-hCG level was higher statistically significantly in Group 2 than Group 1 and 3 ( $\mathrm{p}<0.001) .100 \mathrm{mIU} / \mathrm{mL}$ was accepted as a cut-off value by using the receiver operating characteristic curve. According to $100 \mathrm{mIU} / \mathrm{mL}$, sensitivity, specificity, positive predictive and negative predictive values were calculated as $71.2,100,100$, and $65.1 \%$, respectively.

Conclusion: The study showed that the measurement of $\beta$-hCG level in vaginal washing fluid is an efficient and easy diagnostic test for predicting the amount of fluid leaking from the vagina. However, due to the low negative predictive value of the test, it would not be convenient in daily practice. (J Turkish-German Gynecol Assoc 2013; 14: 201-4)

Key words: Beta-human chorionic gonadotropin, premature rupture of membranes, diagnosis

Received: 01 June, 2013

Accepted: 19 September, 2013
Özet

Amaç: Erken membran rüptürünün tanısı için vajinal sıvıda beta-human koryonik gonadotropin ( $\beta$-hCG) seviyesinin ölçümünün yararlı olup olmadığını belirlemek.

Gereç ve Yöntemler: Gebeliğin 24-40. haftaları arasında olan toplam 92 gebe bu çalışmaya dahil edildi. Vajinadan sıvı geldiği görülen hastalar Grup 1, vajinadan sıvı gelmeyenler Grup 2 and şüpheli sıvı gelişi olan hastalar Grup 3 olarak sınıflandırıldı. Hastaların vajinal sıvıdaki $\beta$-hCG seviyelerinin ölçümü için posterior vajinal fornixin $5 \mathrm{~mL}$ salin ile elde edilen yıkantı suyu kullanıldı. Receiver operator curve (ROC) analizi yapılarak doğru tanı için gereken eşik seviye belirlendi.

Bulgular: Vajinal sıvıda $\beta$-hCG seviyesi Grup 1 için, $20.5 \pm 25.0 \mathrm{mIU} / \mathrm{mL}$, Grup 2 için $254.6 \pm 346.8 \mathrm{mIU} / \mathrm{mL}$, Grup 3 için $74.3 \pm 100.8 \mathrm{mIU} / \mathrm{mL}$ olarak ölçüldü. Vajinal $\beta$-hCG seviyesi Grup 2 de Grup 1 ve 3 'ten istatistiksel olarak daha yüksek bulundu $(\mathrm{p}<0.001)$. ROC analizi eğrisi kullanılarak eşik seviye $100 \mathrm{mIU} / \mathrm{mL}$ olarak kabul edildi. $100 \mathrm{mIU} / \mathrm{mL}$ eşik degree göre; sensitivite, spesifite, pozitif ve negatif prediktif değerler sırasıyla \%71.2, \%100, \%100 ve \%65.1 olarak hesaplandı.

Sonuç: Vajinadan sıvı gelişini ön görmede, vajinal yıkama sıvısında $\beta$-hCG seviyesinin ölçümünün etkili ve kolay bir tanısal testi olduğu çalışmamızda gösterilmiştir. Bununla birlikte: testin negatif prediktif değerinin düşük olmasından dolayı günlük pratikte kullanımı uygun olmayabilir. (J Turkish-German Gynecol Assoc 2013; 14: 201-4)

Anahtar kelimeler: Beta-human koryonik gonadotropin, erken membran rüptürü, tanı

Geliş Tarihi: 01 Haziran 2013

Kabul Tarihi: 19 Eylül 2013

\section{Introduction}

Premature rupture of membrane (PROM) is shown in 5-15\% of all term births and in $20-40 \%$ of all preterm births. The most common complication of PROM is infection. Although term births with prolonged PROM are at risk of infection, the main threat involves preterm cases. Infection risk increases concomitantly with a prolonged latent period (1).

Diagnosis of PROM is easy when there is a demonstration of amniotic fluid leakage from the cervix, but more difficult when there is doubt surrounding whether PROM has occurred. Failure to identify patients with membrane rupture can result in 
a failure to implement obstetric measures, while false diagnosis can lead to inappropriate interventions such as hospitalisation or labour induction. The diagnosis of PROM usually depends on a combination of factors, including the patient's history, identification of amniotic fluid index (AFI) pooling and ferning, and the nitrazine test $(2,3)$. However, in equivocal cases of PROM, the traditional method has been associated with both false-positive and false-negative results (4).

The absence of a non-invasive "gold standard" test for the diagnosis of membrane rupture has led to the search for alternative biochemical markers. Biochemical substances which have high amniotic concentration, e.g. prolactin (5), alpha-fetoprotein (AFP) (6), insulin like growth factor binding protein-1 (7), foetal fibronectin (8), and deaminooxidase (9), have all have been previously studied.

Beta-human chorionic gonadotropin ( $\beta$-hCG) is produced by trophoblastic tissue, which is present in varying degrees in serum, urine, and amniotic fluid during pregnancy. It is present in $\mathrm{AF}$ as well as maternal blood and urine, at concentrations ranging from approximately 2000-70,000 $\mathrm{mIU} / \mathrm{mL}$ (10). Unfortunately, there is no information available about $\beta$-hCG levels in vaginal fluid. Because $\beta$-hCG is secreted by cervical glands, a certain level should be present in vaginal fluid. Therefore, we measured and compared $\beta$-hCG levels in the vaginal fluid of normal pregnant women, pregnant women with PROM and pregnant women with suspected PROM.

In this study, our aim was to determine the diagnostic value of $\beta$-hCG level in vaginal washing fluid for PROM.

\section{Material and Methods}

This study was conducted at Zeynep Kamil Education and Training Hospital, İstanbul, Turkey, in the Department of Perinatology, from April 2011 to December 2011. The study was approved by the local ethics committee, and written informed consent was obtained from all participants. The pregnant women in their second and third trimester that had normal foetal development in ultrasound in respect of their last menstruation date were included in this study. A history of preterm labour and PROM, multiple pregnancy, uterine pathology and malformation, cervical dilatation more than $2 \mathrm{~cm}$, vaginal bleeding or placenta previa, vaginal contaminations with urine or faeces, or those with no follow-up were excluded from the study. A total of 92 pregnant women at the $24-40^{\text {th }}$ week of gestation were enrolled in the present study. A power analysis was not used to calculate the sample size in each group.

At admission, all patients underwent a sterile speculum examination. Amniotic fluid pooling with or without valsalva manoeuvre was noted. The patients with negative, positive and suspected pooling were classified as Group 1 (28 patients), Group 2 (52 patients) and Group 3 (12 patients), respectively. Group 1 contained patients with amniotic fluid leaking from the vagina upon speculum examination, Group 2 included patients without complaint of amniotic fluid leaking from the vagina, while Group 3 was composed of those patients who complained of vaginal discharge and/or perineal wetness, and these patients were negative for amniotic fluid pooling with or without valsalva manoeuvre on speculum examination.
After taking the history of patients, vaginal examination with a sterile speculum was performed on all patients. Amniotic fluid pooling, drainage of amniotic fluid, blood, urine, meconium or semen with valsalva manoeuvre and cervical dilatation were evaluated. Subsequently, 5 cc of sterile saline was placed in the vagina through the speculum. After a 20 minute waiting period, $3 \mathrm{cc}$ of vaginal washing fluid was removed using a syringe. The fluid was transported to the laboratory within one hour, and then placed into a biochemistry tube for $\beta$-hCG analysis. All of the samples were studied in the same laboratory using the same technique. $\beta$-hCG level was measured and interpreted after the samples were centrifuged 5 minutes at $3000 \mathrm{rpm}$. At the same time, the amniotic fluid index (AFI) of patients was measured with the four quadrant method and recorded. AFI values less than $50 \mathrm{~mm}$ were defined as oligohydramnios and values between 50-80 mm were considered as borderline oligohydramnios.

For statistical analysis, SPSS Software Version 19 (IBM, United States of America) was used. In order to analyse parametric data and perform sub-analysis, ANOVA and post-tukey tests were used, respectively. To analyse non-parametric data and perform subanalysis, Kruskal-Wallis and Mann-Whitney U tests were used, respectively. The chi-square test was utilised to analyse rational data. To determine cut-off values, a receiver operating characteristic (ROC) curve and sensitivity analysis were performed.

\section{Results}

Demographic data for each group are shown in Table 1. There were no statistically significant differences between the groups in terms of age, weeks of gestation, AFI and APGAR (Appearance, Pulse, Grimace, Activity, Respiration) score values ( $\mathrm{p}>0.05)$. The birth weight was calculated as 3330.2 \pm 478.0 for group 1, 2758.2 $\pm 953.5 \mathrm{~g}$ for group 2, and $2428.8 \pm 1105.8 \mathrm{~g}$ for group 3 . The mean birth weight of group 1 was statistically significantly higher than that of group 2 and 3 (Table $1, \mathrm{p}<0.05$ ). No significant difference was observed between the groups in terms of number of gravida, parity and abortus numbers ( $p>0.05$ ). The $\beta$-hCG levels of group 1, 2 and 3 were measured as $20.5 \pm 25.0 \mathrm{mIU} / \mathrm{mL}, 254.6 \pm 346.8 \mathrm{mIU} / \mathrm{mL}$ and $74.3 \pm 100.8$ $\mathrm{mIU} / \mathrm{mL}$, respectively. A statistically significant difference was found between the groups for $\beta$-hCG levels. On the day of the measurement of $\mathrm{hCG}$, the average gestation age was calculated as $38^{+6}, 36^{+6}$ and $35^{+1}$ weeks for groups 1,2 and 3 , respectively. Duration from the day of measurement of hCG to the delivery time was 21 hours for group 1, and 55 hours for groups 2 and 3 . All values were found to be statistically significant when $\beta$-hCG cut-off levels were accepted as 90, 95, 100, 105 or $110 \mathrm{mIU} / \mathrm{mL}$ for predicting certain leakage of fluid from the vagina $(p<0.05)$. ROC curve analysis was used to establish the optimal cut-off concentration for vaginal washing fluid for $\beta$-hCG levels. The optimal cut-off value was found to be $100 \mathrm{mIU} / \mathrm{mL}$ (Figure 1). According to this cut-off point, the sensitivity, specificity, positive and negative predictive value were calculated as $71.2 \%, 100 \%$, $100 \%$ and $65.1 \%$, respectively.

Fluid leaking from the vagina would be considered if the patient's $\beta$-hCG value in their vaginal fluid was higher than $100 \mathrm{mIU} / \mathrm{mL}$. Although patients with $\beta$-hCG values lower than $100 \mathrm{mIU} / \mathrm{mL}$ in 
Table 1. Comparison of maternal age, gestation weeks, amniotic fluid index (AFI), birth weight, APGAR (Appearance, Pulse, Grimace, Activity, Respiration) score and $\beta$-hCG value between the groups

\begin{tabular}{|l|c|c|c|c|}
\hline \multirow{2}{*}{} & \multicolumn{4}{|c|}{ Leaking fluid from the vagina } \\
\cline { 2 - 5 } & $\begin{array}{c}\text { Group 1 } \\
\text { (n=28) } \\
\text { (mean } \pm \text { SD) }\end{array}$ & $\begin{array}{c}\text { Group 2 } \\
\mathbf{( n = 5 2 )} \\
\text { (mean } \pm \text { SD) }\end{array}$ & $\begin{array}{c}\text { Group 3 } \\
\text { (n=12) } \\
\text { (mean } \pm \text { SD) }\end{array}$ & p \\
\hline Age (years) & $27.0 \pm 4.5$ & $28.2 \pm 5.4$ & $26.2 \pm 6.3$ & $>0.05$ \\
\hline Gestation weeks & $38.6 \pm 1.9$ & $36.6 \pm 4.5$ & $35.2 \pm 6.4$ & $>0.05$ \\
\hline AFI (mm) & $116.5 \pm 47.9$ & $100.5 \pm 44.4$ & $88.3 \pm 43.5$ & $>0.05$ \\
\hline Birth weight (g) & $3330.2 \pm 478.0$ & $2758.2 \pm 953.5$ & $2428.8 \pm 1105.8$ & $<0.01$ \\
\hline APGAR at 1 min & $8.4 \pm 0.6$ & $7.4 \pm 2.3$ & $7.2 \pm 2.4$ & $>0.05$ \\
\hline APGAR at 5 min & $9.5 \pm 0.7$ & $8.7 \pm 2.0$ & $8.2 \pm 3.1$ & $>0.05$ \\
\hline Beta-hCG (mIU/mL) & $20.5 \pm 25.0$ & $254.6 \pm 346.8$ & $74.3 \pm 100.8$ & $<0.001$ \\
\hline ANOVA test was used. p<0.05 was accepted as statistically significant. & & \\
\hline
\end{tabular}

the vaginal fluid were more likely to have no probability of fluid leaking from the vagina, water flow was detected in $34.9 \%$ of these patients. $\beta$-hCG values were found to be lower than 100 $\mathrm{mIU} / \mathrm{mL}$ in all patients without fluid leaking from the vagina.

\section{Discussion}

PROM is associated with infectious morbidity in the mother and foetus, cord accidents, and imminent term or preterm labour. For these reasons, its correct diagnosis is very important. The history of the patient is often sufficient for diagnosis in $90 \%$ of cases of suspected PROM. Although an accurate diagnosis can be made with intra-amniotic injections of dye, both patients and doctors are reluctant to go through such an invasive procedure. An ideal laboratory diagnostic technique should be acceptable to both patients and clinicians and should be non-invasive, accurate and rapid. The use of biochemical markers (confirmation of AFI components, such as AFP, foetal fibronectin, or insulin-like growth factor-binding protein-1 in the vaginal fluid) seems to present a reasonable alternative method for diagnosing PROM (6-8). All of these markers have advantages and disadvantages. However, they have not been popular because of their complexity and cost.

The other biochemical marker used for the accurate diagnosis of PROM is $\beta$-hCG in vaginal fluid. It does not require additional instruments when a commercial $\beta$-hCG kit for pregnancy testing is available. The advantages of the $\beta$-hCG test include the low cost and rapid results.

In a study published by Kim et al. (11), $\beta$-hCG cut-off value of PROM was estimated in 120 patients and when the cut-off value was accepted as $39.8 \mathrm{mIU} / \mathrm{mL}$, the sensitivity, specificity, positive and negative predictive values were reported as $95.5 \%, 94.7 \%, 91.3 \%$ and $97.3 \%$, respectively. They showed that the $\beta$-hCG values in vaginal washing fluid of patients with pooling was significantly higher than in patients with no pooling, in parallel to our study. However, in contrast to our work, they evaluated preterm and term pregnancies as different groups. Although the cut-off value accepted by Kim et al. (11) was lower than our study, the negative prediction value was higher.
In a study conducted by Mangano et al. (12), 52 patients were evaluated and divided into three groups: patients with clinically confirmed membrane rupture as group 1 $(n=21)$, patients with suspected membrane rupture as group $2(\mathrm{n}=11)$, and the control group without membrane rupture as group $3(n=20)$. In this study, the $\beta$-hCG cut-off value in the vaginal washing fluid was detected as $100 \mathrm{mIU} / \mathrm{mL}$ with regard to prediction of pooling. In another study, Esim et al. (13) examined 141 patients for $\beta$-hCG in vaginal washing fluid; they declared the optimal $\beta$-hCG cut-off value to be $65 \mathrm{mIU} / \mathrm{mL}$. According to this, sensitivity, specificity, positive and negative predictive values were calculated as $68 \%, 95 \%, 82 \%$ and $90 \%$, respectively. Unlike our study, the values of sensitivity and specificity for the second and third trimester were compared separately and sensitivity was found to be higher in the second trimester. Therefore, it was suggested that testing $\beta$-hCG in vaginal fluid in the second trimester could be more convenient. Anai et al. (14) evaluated $\beta$-hCG as a marker for PPROM and established the vaginal $\beta$-hCG concentration ranges of a subset of patients without PPROM in the first, second, and third trimesters. These investigators demonstrated a definitive difference in mean $\beta$-hCG concentrations of subjects with PPROM and those without. They considered that there was a significant difference in the second and third trimesters using a vaginal $\beta$-hCG threshold concentration of $50 \mathrm{mIU} / \mathrm{mL}$. In a study conducted by Ni et al. (15), $\beta$-hCG, AFP and IL-6 markers were investigated in vaginal fluid. According to the ROC analysis, the sensitivity and specificity were $97.7 \%$ and $100 \%$ for AFP, and $95.1 \%$ and $89.5 \%$ for $\beta$-hCG, respectively. They found that AFP had highest diagnostic value. In the present study, sensitivity and specificity were found to be $72.1 \%$ and $100 \%$, respectively, for $\beta$-hCG in vaginal fluid.

As can be seen above, different cut-off levels, sensitivities, specificities, positive and negative predictive values for $\beta$-hCG in vaginal washing fluid have been reported in various studies for the accurate detection of PROM. These different results could have arisen from reasons such as the existence of a difference in the number of samples, including. In addition, patients with vaginal bleeding were included in some studies. 


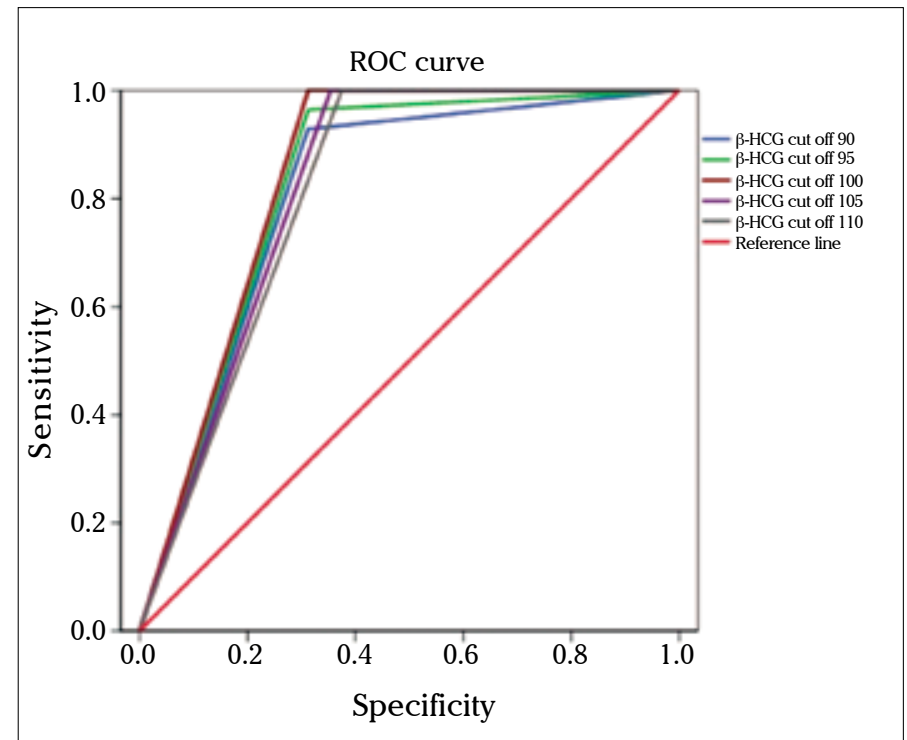

Figure 1. Receiver operating characteristic (ROC) curve analysis

As already known, cut-off values are significantly affected by the number of samples. Also, $\beta$-hCG values may vary from laboratory to laboratory and $\beta$-hCG level in amniotic fluid of term and preterm pregnancies may vary. In the studies discussed, the term and preterm groups were not homogeneous in terms of pregnancy.

In conclusion, we believe that $\beta$-hCG measurements in vaginal fluid would be accurate for diagnostic testing for prediction of PROM. Also, it can be performed quickly and easily. Because it has a low negative predictive value, diagnostic confusion may occur. Extended studies are needed to determine the cut-off value of $\beta$-hCG in the diagnosis of PROM.

Ethics Committee Approval: Ethics Committee Approval was obtained from hospital ethics committee

Informed Consent: Informed consent form was obtained from all patients

Peer-review: Externally peer-reviewed.

Author contributions: Concept - E.Ç., E.K.; Design - E.Ç, O.T.; Supervision - E.Ç., O.T.; Resource - O.T., M.R.A.; Materials - O.T., S.S.; Data Collection\&/or Processing - O.T.; Analysis\&/or Interpretation - O.T.; Writing M.R.A., S.S.; Critical Reviews - E.K.

Conflict of Interest: The authors declared no conflict of interest.

Financial Disclosure: The authors declared that this study received no financial support.

\section{References}

1. Garite TJ. Premature rupture of the membranes: the enigma of the obstetrician. Am J Obstet Gynecol 1985; 151: 1001-5. [CrossRef]

2. Gibbs RS, Blanco JD. Premature rupture of the membranes. Obstet Gynecol 1982; 60: 671-9.

3. Mills AM, Garioch DB. Use of the nitrazine yellow swab test in the diagnosis of ruptured membranes. Br J Obstet Gynaecol 1977; 84: 138-40.

4. Friedman ML, McElin TW. Diagnosis of ruptured fetal membranes. Am J Obstet Gynecol 1969; 104: 544-50. [CrossRef]

5. Phocas I, Sarandakou A, Kontoravdis A, Chryssicopoulos A, Zourlas PA. Vaginal fluid prolactin: a reliable marker for the diagnosis of prematurely ruptured membranes. Comparison with vaginal fluid alpha-fetoprotein and placental lactogen. Eur J Obstet Gynecol Reprod Biol 1989; 31: 133-41. [CrossRef]

6. Gaucherand P, Guibaud S, Rudigoz RC, Wong A. Diagnosis of premature rupture of the membranes by the identification of alphafeto-protein in vaginal secretions. Acta Obstet Gynecol Scand 1994; 73: 456-9. [CrossRef]

7. Lockwood CJ, Wein R, Chien D, Ghidini A, Alvarez M, Berkowitz RL. Fetal memrane rupture is associated with the presence of insulşn-like growth factorbinding protein-1 in vaginal secretions. Am J Obstet Gynecol 1994; 171: 146-50. [CrossRef]

8. Eriksen NL, Parisi VM, Daoust S, Flamm B, Garite TJ, Cox SM. Fetal fibronectin: a method for detecting the presence of amniotic fluid. Obstet Gynecol 1992; 80: 451-4.

9. Gaucherand P, Guibaud S, Awada A, Rudigoz RC. Comparative study of three amniotic fluid markers in premature rupture of membranes: fetal fibronectin, alpha-fetoprotein, diamino-oxydase. Acta Obstet Gynecol Scand 1995; 74: 118-21. [CrossRef]

10. Kletzky OA, Rossman F, Bertolli SI, Platt LD, Mishell DR Jr. Dynamics of human chorionic gonadotrophin, prolactin, and growth hormone in serum and amniotic fluid throughout normal human pregnancy. Am j Obstet Gynecol 1985; 151: 878-84. [CrossRef]

11. Kim YH, Park YW, Kwon HS, Kwon JY, Kim BJ. Vaginal fluid betahuman chorionic gonadotropin level in the diagnosis of premature rupture of membranes. Acta Obstet Gynecol Scand 2005; 84: 802-5. [CrossRef]

12. Mangano B, Diani F, Faccini G, Zatti N, Zardini E. Proposal of a new test for the diagnosis of PROM based on the determination of hCG in the washing fluid of the posterior vaginal fornix. Minerva Ginecol 2000; 52: 185-8.

13. Esim E, Turan C, Unal O, Dansuk R, Cengizglu B. Diagnosis of premature rupture of membranes by identification of beta-HCG in vaginal washing fluid. Eur J Obstet Gynecol Reprod Biol 2003; 107: 37-40. [CrossRef]

14. Anai T, Tanaka Y, Hirota Y, Miyakawa I. Vaginal fluid hCG levels for detecting premature rupture of membranes. Obstet Gynecol 1997; 89: 261-4. [CrossRef]

15. Ni CY, Jia WX, Yi WM, Feng LH, Yu LZ. Practicability of using vaginal fluid markers in detecting premature rupture of membranes. Clin Biochem 2003; 40: 542-5. [CrossRef] 